\title{
The Role of Oxidative Stress in Carcinogenesis Induced By Metals in Breast Cancer Egyptian Females Sample at Dakahlia Governorate
}

\author{
Ahmed R. Ragab ${ }^{1 *}$, Omar Farouk², Mostafa M. Afify ${ }^{3}$, Afaf M. Attia ${ }^{1}$, Ayman El Samanoudy ${ }^{4}$, Yasmeen M. Taalab ${ }^{1}$
}

${ }^{1}$ Department of Forensic Medicine and Clinical Toxicology, Faculty of Medicine, Mansoura University, Mansoura, Egypt

${ }^{2}$ Surgical Oncology Unit, Oncology Center, Mansoura University, Mansoura, Egypt

${ }^{3}$ Department of Forensic Medicine and Clinical Toxicology, Faculty of Medicine, Beni Suef University, Beni Suef, Egypt

${ }^{4}$ Department of Biochemistry, Faculty of Medicine, Mansoura University, Mansoura, Egypt

\begin{abstract}
Trace metals and metals induced Oxidative stress have been implicated in breast carcinogenesis. Our study aimed to evaluate alteration of trace metals in breast tissue, oxidative stress and antioxidant status in breast cancer patients. This study included 120 female patients: 100 with breast cancer and 20 with benign breast diseases. Trace metals in breast tissue, lipid peroxidation and oxidative status were assessed. The present Results showed a significant increase in lead, cadmium, chromium, nickel and iron concentrations in malignant breast tissues compared to control group ( $P$ < 0.001). Also, a significant decline in Glutathione-S-transferase (GST), Glutathione Reductase (GR) and Total Antioxidant Capacity (TAC) levels; however a significant rise in Malondialdehyde (MDA) and Ferritin levels was detected in patients with breast cancer compared to controls. In conclusion, the alteration of the elemental content in cancerous breast tissues and the disruption of oxidant/antioxidant balance highlight the role of trace metals in cancer development.
\end{abstract}

Keywords: Trace metals; Breast cancer; Oxidative stress; Lipid peroxidation; Antioxidants.

\section{Introduction}

Breast cancer accounts for $16 \%$ of all cancer deaths among women globally, according to the report by the World Health Organization. It is the most common solid tumour diagnosed in women [1]. Although the incidence of breast cancer increases with age, certain lifestyle and environmental factors play an important role on breast cancer risk. In Egypt, breast cancer is the most common cancer among women, representing $18.9 \%$ of total cancer cases $(35.1 \%$ in women and $2.2 \%$ in men) among the Egypt National Cancer Institute (NCI) series of 10,556 patients during the year 2001 [2].

Environmental factors also play a decisive role in breast carcinogenesis together with life-long dietary habits. Chronic exposures to various heavy metals are nearly unavoidable in daily life, such as from airborne particles, soil, water and subsequently food [3]. In Egypt, Recent data indicate that the current levels of copper, chromium, cadmium, lead, manganese, vanadium, arsenic, nickel, antimony and titanium were higher than those considered safe for the general population [4].

Multiple reports show that metallic compounds could function as estrogen disruptors, while other studies underline the connection between the exposure to metals or metal compounds and breast cancer risk [5]. Metals like arsenic, cadmium, chromium, lead, nickel, and others are a major source of oxidative stress. Substantial data suggest that oxidative stress is involved in the development of breast cancer. It is apparent that some trace metals are claimed to be carcinogenic and capable of inducing a toxic effect through the formation of reactive oxygen species (ROS) and acting as cofactors in the oxidative damage of biological macromolecules and deoxyribonucleic acid (DNA) [6].

\section{The Aim of the Work}

The aim of this study is to evaluate the alteration of trace metals in breast tissue, the level of oxidative stress and antioxidant status in the blood of breast cancer patients and to investigate the relationship between these parameters.

\section{Subjects and Methods}

\section{Patient selection}

The present study was conducted on 120 female attending Oncology Center, Mansoura University, and Dakahlia Governorate, Egypt. Their ages ranged from 30-70 years. Relevant information was obtained from each patient before surgery regarding residence, occupational history, smoking habits, medical history and reproductive history. Informed consent was obtained to get the biopsy.

\section{Exclusion criteria}

Based on the history; patients with positive family history of breast carcinoma, smokers, and patients received either hormonal therapy or any treatment for the tumour, patient with chronic disease (e.g. diabetes mellitus, liver dysfunction, rheumatoid arthritis...etc) were excluded from the study.

\section{Study groups}

Patients were divided into 2 groups: the breast cancer group (Cancerous group): 100 female patients who have histo-pathologically confirmed breast carcinoma lesions. The control group (Non-cancerous group): 20 female patients that have non-risky non-proliferative benign breast disease.

\section{Samples collection}

Five $\mathrm{ml}$ blood sample and one gm of breast tissue were obtained

*Corresponding author: Ahmed R. Ragab, Department of Forensic Medicine and Clinical Toxicology, Faculty of Medicine, Mansoura University, Mansoura, Egypt, Tel: 050-344725; E-mail: ahmedrefat1973@yahoo.com

Received November 13, 2013; Accepted January 25, 2013; Published January 27, 2014

Citation: Ragab AR, Farouk O, Afify MM, Attia AM, Samanoudy AE, et al. (2014) The Role of Oxidative Stress in Carcinogenesis Induced By Metals in Breast Cancer Egyptian Females Sample at Dakahlia Governorate. J Environ Anal Toxicol 4: 207. doi: 10.4172/2161-0525.1000207

Copyright: (c) 2014 Ragab AR, et al. This is an open-access article distributed under the terms of the Creative Commons Attribution License, which permits unrestricted use, distribution, and reproduction in any medium, provided the original author and source are credited. 


\begin{tabular}{|c|c|c|c|c|}
\hline $\begin{array}{c}\text { Trace Metals } \\
(\boldsymbol{\mu g} / \mathbf{g} \text { tissue) }\end{array}$ & $\begin{array}{c}\text { Control group } \\
\text { (Mean } \pm \text { SD) }\end{array}$ & $\begin{array}{c}\text { Cancerous Group } \\
\text { (Mean } \pm \text { SD) }\end{array}$ & t-test & $\boldsymbol{P}$ - value \\
\hline Lead & $0.10 \pm 0.02$ & $0.21 \pm 0.07$ & 5.54 & $\mathrm{P}<0.001^{* *}$ \\
\hline Cadmium & $0.05 \pm 0.02$ & $0.22 \pm 0.14$ & 6.57 & $\mathrm{P}<0.001^{* *}$ \\
\hline Chromium & $0.16 \pm 0.03$ & $0.38 \pm 0.15$ & 4.87 & $\mathrm{P}<0.001^{* *}$ \\
\hline Nickel & $0.24 \pm 0.04$ & $0.72 \pm 0.24$ & 5.84 & $\mathrm{P}<0.001^{* *}$ \\
\hline Iron & $5.02 \pm 1.21$ & $11.89 \pm 2.86$ & 6.63 & $\mathrm{P}<0.001^{* *}$ \\
\hline Zinc & $11.30 \pm 4.32$ & $15.04 \pm 10.24$ & 1.36 & $\mathrm{P}=0.539$ \\
\hline
\end{tabular}

${ }^{*} \mathrm{P}<0.05 /{ }^{* *} \mathrm{P} \leq 0.01$

Table 1: Levels of different trace metals measured in breast tissue of the Cancerous group in relation to the control group.

\begin{tabular}{|c|c|c|c|c|}
\hline $\begin{array}{c}\text { Oxidative Stress } \\
\text { parameters }\end{array}$ & $\begin{array}{c}\text { Control group } \\
\text { (Mean } \pm \text { SD) }\end{array}$ & $\begin{array}{c}\text { Cancerous Group } \\
(\text { Mean } \pm \text { SD) }\end{array}$ & t- test & $P$-value \\
\hline GST $(\mu \mathrm{mol} / \mathrm{min} / \mathrm{ml})$ & $381.08 \pm 57.77$ & $234.94 \pm 66.35$ & -5.9 & $\mathrm{P}<0.05^{*}$ \\
\hline $\mathbf{G R}(\mathrm{U} / \mathrm{l})$ & $22.15 \pm 3.30$ & $14.97 \pm 3.56$ & -4.21 & $\mathrm{P}<0.05^{*}$ \\
\hline $\mathbf{T A C}(\mathrm{mm} / \mathrm{l})$ & $0.50 \pm 0.12$ & $0.29 \pm 0.08$ & 4.94 & $\mathrm{P}<0.001^{* *}$ \\
\hline Ferritin $(\mathrm{ng} / \mathrm{ml})$ & $73.92 \pm 12.06$ & $283.15 \pm 22.58$ & 8.58 & $\mathrm{P}<0.001^{* *}$ \\
\hline MDA $(\mu \mathrm{mol} / \mathrm{dl})$ & $1.87 \pm 0.12$ & $4.05 \pm 0.85$ & 6.49 & $\mathrm{P}<0.001^{* *}$ \\
\hline
\end{tabular}

${ }^{*} \mathrm{P}<0.05 /{ }^{* *} \mathrm{P} \leq 0.01$

Table 2: Levels of different oxidative Stress parameters measured in the Cancerous group in relation to the control group.

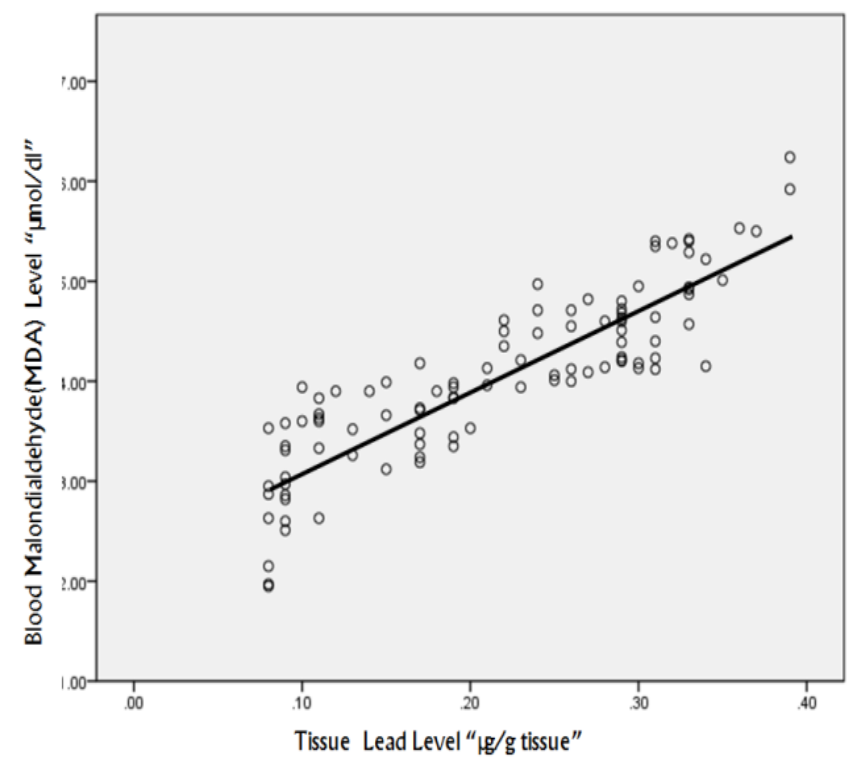

Figure 1: A scattered spot curve showing significant direct correlation between tissue $\mathrm{Pb}$ level $(\mu \mathrm{g} / \mathrm{g}$ tissue) and plasma MDA level $(\mu \mathrm{mol} / \mathrm{dl})$ in patients with breast cancer.

from each patient. Samples were kept in polyethylene containers and frozen immediately at -20c until analysis. All samples were transferred to the laboratory in an ice box using ice chips to preserve them.

\section{Biochemical assays}

Analysis of toxic and trace metals: Analysis of the studied heavy metals and trace elements [lead $(\mathrm{Pb})$; cadmium $(\mathrm{Cd})$; chromium $(\mathrm{Cr})$; Nickel $(\mathrm{Ni})$; Iron $(\mathrm{Fe})$ and zinc $(\mathrm{Zn})]$ was done by Perkin Elmer 2380 Atomic Absorption Spectrophotometer after wet ashing of tissue specimens using reagent-grade $\mathrm{HNO}_{3}$ and $\mathrm{HClO}_{4}$ according to Eads and Lambdin [7] and Stockwell and Corns [8]. Instrument start- up and optimization were carried out as detailed in the operating manual. The source of the flame was an air- acetylene mixture. Wavelengths were set at 228.8, 217.6, 232, 357.9 and $213.9 \mathrm{~nm}$ for $\mathrm{Cd}, \mathrm{Pb}, \mathrm{Ni}, \mathrm{Cr}$ and $\mathrm{Zn}$ respectively.

\section{Oxidative stress assays:}

1. Measurement of Glutathione-S-Transferase Activity (GST): The assay was undertaken using the method of Habing et al. [9]. In this method, the activity was measured spectrophotometrically by following the increase in the yellow color development as a result of conjugation of 1-chloro-2, 4-dinitrobenzene (CDNB) with GSH by Glutathione-S-Transferase.

2. Measurement of Glutathione Reductase Activity (GR): Glutathione reductase catalysis the reduction of glutathione (GSSG) in the presence of NADPH, which is oxidized to $\mathrm{NADPH}+$ the decrease in absorbance, is measured at $340 \mathrm{~nm}$ according to the method of Goldberg \& Spooner [10].

3. Measurement of plasma total antioxidant activity (TAC): The method used to measure the plasma antioxidant activity, based on the inhibition by ethylbenzothiazole-6-sulfate) (ABTS), which has a characteristic long wave length absorption spectrum showing maxima at 660,734 and $820 \mathrm{~nm}$.

Totalantioxidantactivitywas determined spectrophotometrically according to the ability of the plasma antioxidant to scavenge the 2,2 azinobis (3-ethyl-benzothiazoline-6 sulfate)(ABTS) radical, inhibiting its absorption at $734 \mathrm{~nm}$. The method of preparation and measurement was carried out according to Rice-Evans and Miller [11].

4. Measurement of plasma ferritin level: The CALBIOTECH INC. (CBI), Ferritin ELISA kit is used for the quantitative measurement of Ferritin in human serum or plasma. The method of measurement was carried out according to the manufacturer construction. It is a solid phase direct sandwich ELISA method. Read the absorbance of each sample was read on strip ELISA Reader (statfax) at $450 \mathrm{~nm}$ Dawson et al. [12].

5. Measurement of plasma malondialdehyde (MDA): Plasma proteins are precipitated by addition of trichloroacetic acid (TCA). Then, thiobarbituric acid (TAB) reacts with malondialdehyde (MDA) to form thiobarbituric acid reactive product which is measured at $534 \mathrm{~nm}$ [13].

\section{Statistical analysis}

Statistical analysis was based on comparing the values of control group as compared to the cancerous group. There was a statistical analysis of the entire data with the help of the present SPSS statistical package Version 19. This data was further presented as mean \pm Standard Deviation of Means (S.D.M). There was also a comparison exercise done between the two groups that was carried out with the help of t-test and $\mathrm{p}$ value was considered statistically significant if $<0.05$.

\section{Results}

The levels of lead $(\mathrm{Pb})$; cadmium $(\mathrm{Cd})$; chromium (Cr); Nickel (Ni); Iron $(\mathrm{Fe})$ and zinc $(\mathrm{Zn})$ in breast tissue are shown in Table 1 . The results show a remarkable and significant increase in the mean levels of $(\mathrm{Pb}$, $\mathrm{Cd}, \mathrm{Cr}, \mathrm{Ni}$ and $\mathrm{Fe}$ ) in cancerous breast tissue group as compared to its levels in control tissue group while zinc has no significant difference between studied groups.

Table 2 shows the extent of lipid peroxidation and the antioxidant status in serum of breast cancer group in relation to the control group. 
In this study, the levels of GST, GR and TAC measured in breast cancer group were significantly lower than those in controls. However, MDA and Ferritin levels were significantly higher than those in controls.

Figures 1,2 and 3 illustrated a significant positive (direct) correlation between tissue lead levels and plasma MDA in patients with breast cancer $(\mathrm{r}=0.876, \mathrm{p}<0.0001)$, cadmium $(\mathrm{r}=0.991, \mathrm{p}<0.0001)$ and iron $(\mathrm{r}=0.518, \mathrm{p}<0.0001)$ respectively.

Figure 4 showed a significant negative (indirect) correlation

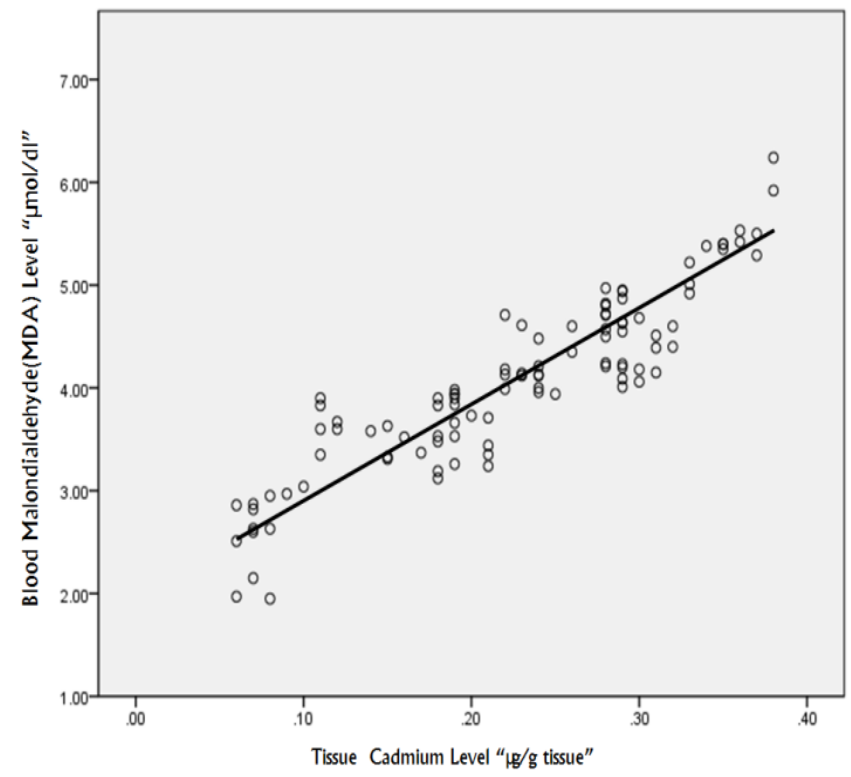

Figure 2: A scattered spot curve showing significant direct correlation between tissue Cd level $(\mu \mathrm{g} / \mathrm{g}$ tissue) and plasma MDA level $(\mu \mathrm{mol} / \mathrm{dl})$ in patients with breast cancer.

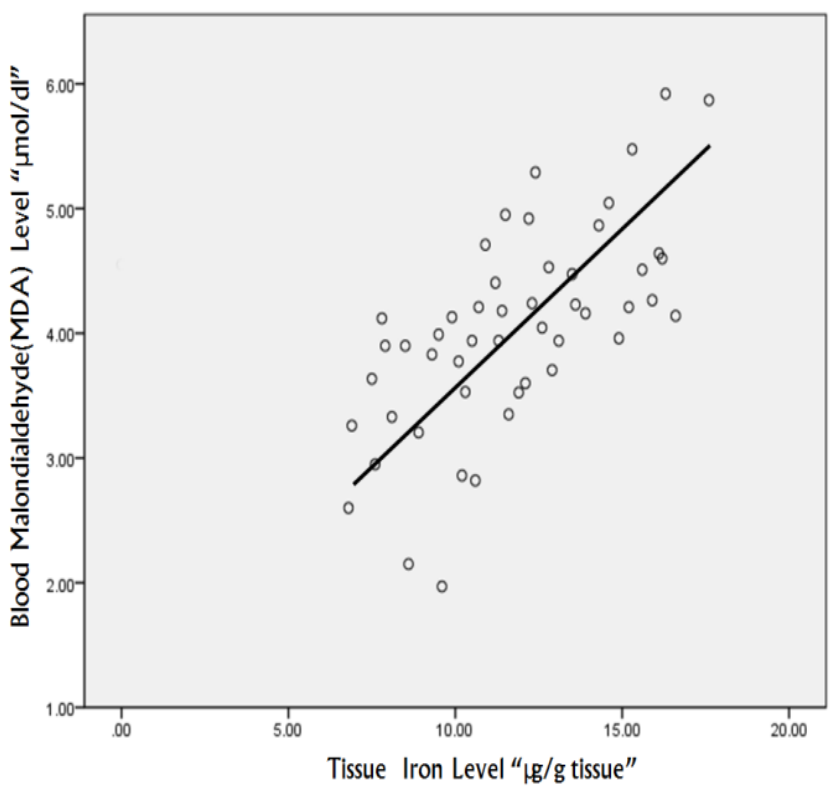

Figure 3: A scattered spot curve showing significant direct correlation between tissue Fe level ( $\mu \mathrm{g} / \mathrm{g}$ tissue) and plasma MDA level $(\mu \mathrm{mol} / \mathrm{dl})$ in patients with breast cancer.

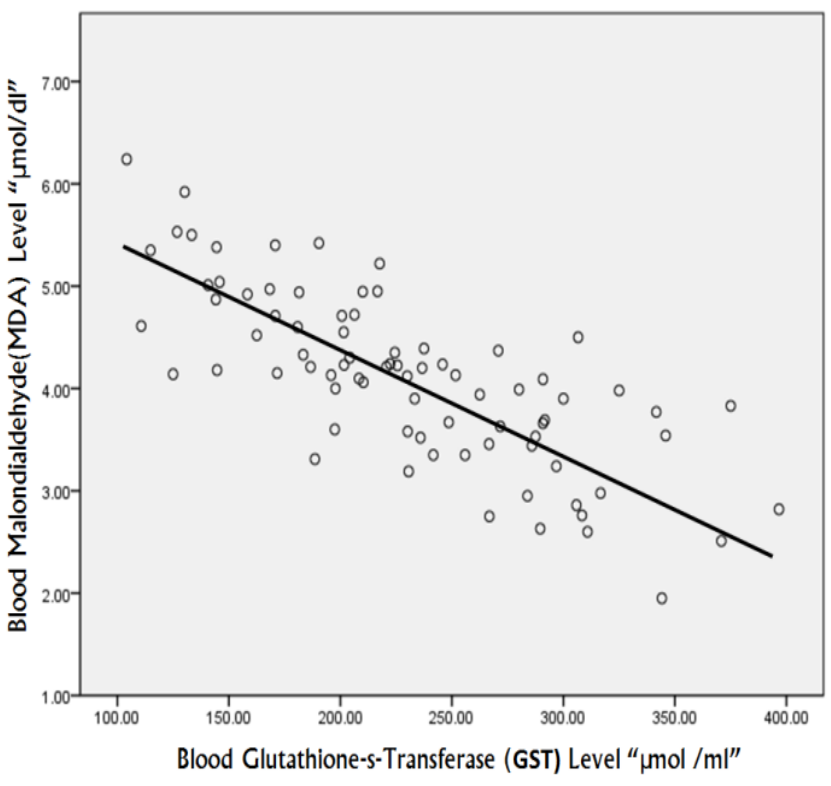

Figure 4: A scattered spot curve showing significant indirect correlation between plasma GST $(\mu \mathrm{mol} / \mathrm{min} / \mathrm{ml})$ and plasma MDA level $(\mu \mathrm{mol} / \mathrm{dl})$ in patients with breast cancer.

between plasma GST level $(\mu \mathrm{mol} / \mathrm{min} / \mathrm{ml})$ and plasma MDA level $(\mu \mathrm{mol} / \mathrm{dl})$ in patients with breast cancer $(\mathrm{r}=0.738, \mathrm{p}<0.0001)$.

\section{Discussion}

Trace elements and toxic heavy metals have critical roles in cancer biology. A large number of epidemiological studies indicate a close association between heavy metals and development of breast cancer such as lead $(\mathrm{Pb})$, Copper $(\mathrm{Cu})$, zinc $(\mathrm{Zn})$, arsenic (As), cadmium $(\mathrm{Cd})$, and nickel $(\mathrm{Ni})$, which are found naturally in the environment [14]. In the current study, the concentrations of six heavy metals (lead, cadmium, chromium, Nickel, Iron and zinc) were estimated in the tissue samples of patients with breast cancer; it was apparent that a statistically significant elevation of lead, cadmium, chromium, nickel and iron concentrations was detected in breast tissue of women having malignant breast tumors in comparison to control group. The present results are run in parallel with those obtained by Pasha et al. [15], da Silva et al. [16] and Romanowicz-Makowska et al. [17].

Metals can be carcinogenic in various forms including free ions, metal complexes, or particles as well as soluble metal compounds. In general, metal carcinogenicity and genotoxicity are based on three main mechanisms, namely, oxidative stress, DNA repair modulation, and disturbances of signal transduction pathways [18]. Interestingly, some trace metals are claimed to be carcinogenic and capable of inducing a toxic effect through the formation of ROS and acting as cofactors in the oxidative damage of biological macromolecules and DNA. However, their exact role in carcinogenesis is still unclear [19].

Siddiqui et al. [20] analyzed blood, tumor tissue and breast adipose tissue from tumor free sections of mammary tissue of women with malignant and benign breast tumors. The Blood lead was significantly higher in malignant cases than in those of control. Also, lead level was insignificantly higher in malignant and benign tumor tissues when compared with normal tumor free breast tissue. Most observed mechanisms of lead carcinogenicity involve direct DNA damage, 
Citation: Ragab AR, Farouk O, Afify MM, Attia AM, Samanoudy AE, et al. (2014) The Role of Oxidative Stress in Carcinogenesis Induced By Metals in Breast Cancer Egyptian Females Sample at Dakahlia Governorate. J Environ Anal Toxicol 4: 207. doi: 10.4172/2161-0525.1000207

Page 4 of 5

oxidative DNA damage through ROS generation, clastogenicity, endocrine disrupters, or inhibition of DNA synthesis or repair [21].

The increased levels of $\mathrm{Cd}, \mathrm{Cr}$ and $\mathrm{Ni}$ in cancerous breast tissue samples and their suggested role in tumor development could be related to their disruption of the oxidative balance, production of oxidative DNA damage and inhibition of DNA repair [22]. Additionally, they functions also as an important class of endocrine disrupters [21]. Cadmium affects cell proliferation, differentiation, apoptosis and signal transduction by enhancement of protein phosphorylation and activation of transcription and translation factors [23]. Moreover, the demand for increased blood supply for a growing tumor provides a basis for the accumulation of many elements [19].

Metals such as iron and zinc were involved in breast tumorigenesis and their suggested role in tumor development could be related to their action as enzymatic co-factors involved in carcinogenesis [24]. In addition, zinc belongs to the group of oxidant metals causing disruption of the oxidative balance. Iron can also promote carcinogenesis by causing tissue damage as it acts as a catalyst in the conversion of hydrogen peroxide to free radical ions that attack cellular membranes, breaks DNA strands, inactivate enzymes and initiate lipid peroxidation [25]. In such conditions up regulated ferritin expression might be a compensatory protective mechanism [26]. The main regulator of ferritin synthesis is the iron level, so In the present study, a significant increase in ferritin levels in breast cancer group of patients versus control group $(\mathrm{p}<0.001)$ with a significant positive correlation with iron level was detected.

Disruption of metal ion homeostasis may lead to oxidative stress, a state where increased formation of ROS overwhelms body antioxidant protection and subsequently induces DNA damage, lipid peroxidation, protein modification and carcinogenesis [19]. Our study revealed marked disruption in the oxidative stress markers as evidenced by a significant decrease in the glutathione-s-transferase, glutathione reductase and total antioxidant capacity levels in breast cancer group of patients versus control group $(\mathrm{p}<0.001)$. These finding run in parallel, with those obtained by Kumaraguruparana et al. [27] and Kasapović et al. [28] they also found that GST, GR and TAC were significantly decreased in breast cancer patients. However, contrary to our findings, raised GST and GR in the patients with breast cancer have also been reported [29].

In recent years, using MDA as a marker of oxidative stress, there has been a growing interest in studying the role played by lipid peroxidation in cancer progression. MDA is low molecular weight aldehyde that can be produced from free radical attack on polyunsaturated fatty acids. Our results showed a significantly increase in MDA level in breast cancer patients as compared to controls thus agreeing with the previous studies [30,31].

The probable reason for the elevated level of serum lipid peroxide in breast carcinoma may be due to defective antioxidant system which leads to the accumulation of lipid peroxides in cancer tissue which are released into the blood stream [32]. MDA constitutes a highly cytotoxic major aldehyde final peroxyl radical product of lipid peroxidation. It is claimed to be an inhibitor to protective enzymes. Hence, it could have both mutagenic and carcinogenic effects [33].

In this study, a statistically significant negative correlation between plasma means levels of MDA and GST activities. The increased level of lipid peroxidation products plays a role in tumor growth. The high MDA level could be explained by defect in the antioxidant system with accumulation of lipid peroxides in cancer tissue as stated by
Kumaraguruparan et al. [27]. Furthermore, Sener et al. [34] reported statistically significant lower total antioxidant capacity with significantly higher serum MDA levels in breast cancer patients compared to control subjects.

In addition, the present study showed a statistically significant positive correlation between levels of Lead, Cadmium and Iron in breast tissue and median MDA in plasma. This may be explained by the fact that elevation of these metals could lead to formation of free radicals or other reactive oxygen species. Valko et al. [35] stated that disruption of metal homeostasis may lead to uncontrolled metal-mediated formation of deleterious free radicals participating in the modifications to DNA bases and enhanced lipid peroxidation with subsequent formation of MDA.

Detailed studies by Pasha et al. [15], da Silva et al. [16], RomanowiczMakowska et al. [17] and Siddiqui et al. [20] detect and compare some heavy metals in benign and malignant breast lesions. In addition other studies by Kumaraguruparana et al. [27], Kasapović et al. [28], Gupta et al. [30] and Sreenivasa et al. [31] investigate antioxidant status and lipid peroxidation in the blood of breast cancer patients. While our study investigates the correlation between the trace metals and oxidative stress parameter in breast cancer patients in our country.

\section{Conclusion}

The increased levels of trace elements and metals ( $\mathrm{Pb}, \mathrm{Cd}, \mathrm{Cr}, \mathrm{Fe}$ and $\mathrm{Zn}$ ) in cancerous tissues in comparison to benign breast tissues highlights the role for these trace elements in the initiation, promotion and progression of breast cancer. It seems likely, that the increased levels of these elements could lead to formation of free radicals or other reactive oxygen species inducing oxidative stress which affects adversely DNA and thereby causing breast cancer. It is recommended to use trace elements and antioxidant activity as biomarkers for breast cancer and its progression and also prevention of this disease.

\section{References}

1. (2011) World Health Organization FS.

2. Elattar IA, Hassan NM, Lamee MM, Elbasmy AA (2005) Cancer profile at the National Cancer Institute, Egypt, 2002-2003. Journal of Clinical Oncology. ASCO Annual Meeting Proceedings. 23: 16S.

3. Jevtic M, Velicki R, Popovic M, Cemerlic-Adjic N, Babovic SS, et al. (2010) Dietary influence on breast cancer. J BUON 15: 455-461.

4. Hassanien MA (2009) Risk assessment of atmospheric toxic pollutants over Cairo, Egypt. J Environ Sci 5: 37-57.

5. Siewit CL, Gengler B, Vegas E, Puckett R, Louie MC (2010) Cadmium promotes breast cancer cell proliferation by potentiating the interaction between ERalpha and c-Jun. Mol Endocrinol 24: 981-992.

6. Leonard SS, Bower JJ, Shi X (2004) Metal-induced toxicity, carcinogenesis, mechanisms and cellular responses. Mol Cell Biochem 255: 3-10.

7. Eads EA, Lambdin CE (1973) A survey of trace metals in human hair. Environ Res 6: 247-252.

8. Stockwell PB, Corns WT (1993) The role of atomic fluorescence spectrometry in the automatic environmental monitoring of trace element analysis. J Automat Chem 15: 79-84.

9. Habig WH, Pabst MJ, Jakoby WB (1974) Glutathione S-transferases. The first enzymatic step in mercapturic acid formation. J Biol Chem 249: 7130-7139.

10. Goldberg DM, Spooner RJ (1983) In methods of enzymatic analysis (Bergmeyen, H.V. Ed.) 3rd edn, Veriog Chemie, Deerfield beach, Fi 3: 258-265.

11. Rice-Evans C, Miller NJ (1994) Total antioxidant status in plasma and body fluids. Methods Enzymol 234: 279-293.

12. Dawson DW, Fish DI, Shackleton P (1992) The accuracy and clinical interpretation of serum ferritin assays. Clin Lab Haematol 14: 47-52. 
Citation: Ragab AR, Farouk O, Afify MM, Attia AM, Samanoudy AE, et al. (2014) The Role of Oxidative Stress in Carcinogenesis Induced By Metals in Breast Cancer Egyptian Females Sample at Dakahlia Governorate. J Environ Anal Toxicol 4: 207. doi: 10.4172/2161-0525.1000207

13. Draper HH, Hadley M (1990) Malondialdehyde determination as index of lipid peroxidation. Methods Enzymol 186: 421-431.

14. Florea AM, Büsselberg D (2011) Metals and breast cancer: risk factors or healing agents? J Toxicol 2011: 159619.

15. Pasha Q, Malik SA, Shah MH (2008) Statistical analysis of trace metals in the plasma of cancer patients versus controls. J Hazard Mater 153: 1215-1221.

16. da Silva MP, Zucchi OL, Ribeiro-Silva A, Poletti ME (2009) Discriminant analysis of trace elements in normal, benign and malignant breast tissues measured by total reflection X-ray fluorescence. Spectrochimica Acta Part B 64: 587-592.

17. Romanowicz-Makowska H, Forma E, BryÅ M, Krajewska WM, Smolarz B (2011) Concentration of cadmium, nickel and aluminium in female breast cancer. Pol J Pathol 62: 257-261.

18. Valko M, Rhodes CJ, Moncol J, Izakovic M, Mazur M (2006) Free radicals metals and antioxidants in oxidative stress-induced cancer. Chem Biol Interact 160: $1-40$.

19. Jomova K, Valko M (2011) Advances in metal-induced oxidative stress and human disease. Toxicology 283: 65-87.

20. Siddiqui MK, Jyoti, Singh S, Mehrotra PK, Singh K, et al. (2006) Comparison of some trace elements concentration in blood, tumor free breast and tumor tissues of women with benign and malignant breast lesions: an Indian study. Environ Int 32: 630-637.

21. Martin MB, Reiter R, Pham T, Avellanet YR, Camara J, et al. (2003) Estrogenlike activity of metals in MCF-7 breast cancer cells. Endocrinology 144: 24252436.

22. Leonard SS, Bower JJ, Shi X (2004) Metal-induced toxicity, carcinogenesis, mechanisms and cellular responses. Mol Cell Biochem 255: 3-10.

23. Siewit CL, Gengler B, Vegas E, Puckett R, Louie MC (2010) Cadmium promotes breast cancer cell proliferation by potentiating the interaction between ERalpha and c-Jun. Mol Endocrinol 24: 981-992.

24. Geraki K, Farquharson MJ, Bradley DA (2002) Concentrations of Fe, Cu and $\mathrm{Zn}$ in breast tissue: a synchrotron XRF study. Phys Med Biol 47: 2327-2339.
25. Konemann S, Bolling T, Matzkies F, Willich N, Kisters K, et al. (2005) Iron and iron-related parameters in oncology. Trace Elem Electrolytes 22: 142-149.

26. Cujic D, Stefanoska I, Golubovic S (2011) Serum Ferritin in Healthy Women and Breast Cancer Patients. J Med Biochem 30: 33-37.

27. Kumaraguruparan R, Subapriya R, Kabalimoorthy J, Nagini S (2002)Antioxidant profile in the circulation of patients with fibroadenoma and adenocarcinoma of the breast. Clin Biochem 35: 275-279.

28. Kasapovic J, Pejic S, Todorovic A, Stojiljkovic V, Pajovic SB (2008) Antioxidant status and lipid peroxidation in the blood of breast cancer patients of different ages. Cell Biochem Funct 26: 723-730.

29. Yeh CC, Hou MF, Tsai SM, Lin SK, Hsiao JK, et al. (2005) Superoxide anion radical, lipid peroxides and antioxidant status in the blood of patients with breast cancer. Clin Chim Acta 361: 104-111.

30. Gupta RK, Patel AK, Kumari R, Chugh S, Shrivastav C, et al. (2012) Interactions between oxidative stress, lipid profile and antioxidants in breast cancer: a case control study. Asian Pac J Cancer Prev 13: 6295-6298.

31. Rao CSS, Kumari DS (2012) Changes in Plasma Lipid Peroxidation and the Antioxidant System in Women with Breast Cancer. Int $\mathrm{J}$ of Basic and Appl Sciences 1: 429-438

32. Kumaraguruparan R, Subapriya R, Viswanathan P, Nagini S (2002) Tissue lipid peroxidation and antioxidant status in patients with adenocarcinoma of the breast. Clin Chim Acta 325: 165-170.

33. Ziech D, Franco R, Georgakilas AG, Georgakila S, Malamou-Mitsi V, et al. (2010) The role of reactive oxygen species and oxidative stress in environmenta carcinogenesis and biomarker development. Chem Biol Interact 188: 334-339.

34. Sener DE, Gönenç A, Akinci M, Torun M (2007) Lipid peroxidation and tota antioxidant status in patients with breast cancer. Cell Biochem Funct 25: 377 382

35. Valko M, Leibfritz D, Moncol J, Cronin MT, Mazur M, et al. (2007) Free radicals and antioxidants in normal physiological functions and human disease. Int $\mathrm{J}$ Biochem Cell Biol 39: 44-84. 